ks. Wojciech Węgrzyniak

Uniwersytet Papieski Jana Pawła II w Krakowie

\title{
Starotestamentowe życie nienarodzonych
}

Mimo bogactwa i złożoności literatury starotestamentowej nie znajdziemy na kartach ksiąg Pierwszego Przymierza traktatu o życiu nienarodzonych ${ }^{1}$. Nawet te fragmenty, które mówią o życiu człowieka między poczęciem a narodzeniem, nie są wystarczające, by wysnuwać uogólniające i kompleksowe wnioski. Niemniej jednak Stary Testament w niektórych miejscach odsłania rąbek poglądów na temat początkowego stadium życia - niniejszy artykuł stawia sobie za cel przybliżenie tego, co Biblia mówi na ten temat.

Artykuł składa się z czterech części. W pierwszej zostaną omówione czynniki umożliwiające poczęcie człowieka, w drugiej proponuje się semantyczną analizę terminu technicznego הרה hārāh "począć, być w ciąży”, w trzeciej zostaną poddane analizie cztery główne teksty mówiące o życiu nienarodzonych (Rdz 25, 21-24; Wj 21, 22-25; Hi 10; Ps 139). W ostatniej części zostanie zaproponowana krótka synteza starotestamentowej myśli o życiu w łonie matki.

1 To być może jest powodem, dlaczego w wielu nawet klasycznych opracowaniach pomija się całkowicie kwestię życie nienarodzonych w ST. Nie pisze o tym prawie nic R. De Vaux w Le istituzioni dell'Antico Testamento (Genova ${ }^{3} 1998$ ), C. Westermann w Der Mensch im Alten Testament (Münster 2000) ani A. Wénin w L'homme biblique (Paris ${ }^{2} 2004$ ). Podobnie zresztą jak G. von Rad w Theologie des Alten Testaments (München 1987). Parę myśli możemy spotkać jedynie na kartach H. W. Wolffa, Antropologia dell'Antico Testamento, Brescia ${ }^{4} 2002$, s. 127-130. 


\section{Czynniki umożliwiające poczęcie człowieka}

Stary Testament widzi dwa zasadnicze czynniki początku życia człowieka. Pierwszym czynnikiem jest Bóg. To on jest zarówno Stwórcą pierwszych ludzi (por. Rdz 1, 26-27; 2,7), jak i dawcą pierwszego przykazania, które człowiek otrzymał od Boga:

Bądźcie płodni i rozmnażajcie się, abyście zaludnili ziemię i uczynili ją sobie poddaną; abyście panowali nad rybami morskimi, nad ptactwem powietrznym i nad wszystkimi zwierzętami pełzającymi po ziemi! ( $\mathrm{Rdz} 1,28)$.

Wpływ Boga na początek życia ludzkiego nie ogranicza się do stworzenia Adama i Ewy ani nawet do nakazu rozmnażania się rodzaju ludzkiego. Bóg jest decydującym czynnikiem powstania każdego człowieka. To Pan zamyka łono kobiety, aby nie rodziła ${ }^{2}$ i Pan otwiera jej łono ${ }^{3}$. Jak stwierdzi lapidarnie Anna: „To Pan daje śmierć i życie” (1 Sm 2, 6). Biblia nie ma wątpliwości, że twórcą każdego człowieka jest Bóg.

Drugim czynnikiem początku życia człowieka jest akt seksualny mężczyzny i kobiety. W celu opisania tego aktu Stary Testament używa kliku określeń:

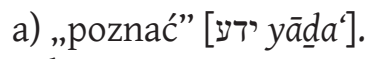

Tak np. opisane jest narodzenie Kaina:

Adam poznał [י]ָּ [יָע] Ewę, swoją żonę. Poczęła i urodziła Kaina i rzekła: „Otrzymałam mężczyznę od Pana" (Rdz 4,1).

Tak samo autor opisuje narodzenie Henocha, syna Kaina:

I poznał [י] Kain swoją żonę, a ona poczęła i urodziła Henocha (Rdz 4, 17).

2 Np. Sary, która mówi Abrahamowi: „Pan zamknął mi łono, abym nie rodziła” (Rdz 16, 2), albo Anny, o której pisze autor 1 Księgi Samuela: „Annę [Elkana] bardzo miłował, mimo że Pan zamknął jej łono. Jej współzawodniczka przymnażała jej smutku, aby ją rozjątrzyć z tego powodu, że Pan zamknął jej łono. (1 Sm 1, 5-6). Rozgniewany Jakub mówi do Racheli: „Czyż to ja, a nie Bóg, odmawiam ci potomstwa?" (Rdz 30, 2).

Pisząc o Lei, autor Księgi Genesis zanotuje: „Gdy Pan widział, że Lea została odsunięta, otworzył jej łono; Rachela zaś była niepłodna” (Rdz 29, 31). Urodziwszy drugiego syna Lea powie: „Usłyszał Pan, że zostałam odsunięta, i dał mi jeszcze to dziecko” (Rdz 29, 33). Tak samo w przypadku Racheli: „A Bóg zlitował się i nad Rachelą; wysłuchał ją Bóg i otworzył jej łono” (Rdz 30, 22). 


\section{Tak również narodzenie Seta:}

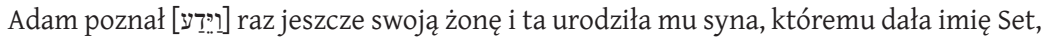
„gdyż - jak mówiła - dał mi Bóg potomka innego w zamian za Abla, którego zabił Kain" $(\operatorname{Rdz} 4,25)^{4}$.

b) „leżeć” [בכש šāknab].

Tak opisane jest narodzenie Issachara:

A gdy Jakub wracał wieczorem z pola, wyszła Lea naprzeciw niego i rzekła: „Do mnie przyjdź, bo nabyłam cię za mandragory mego syna”. I spał z nią [dosł. „leżał z nią”, ,po-

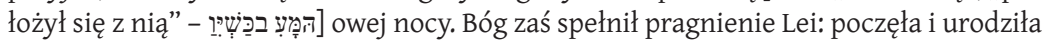
Jakubowi piątego syna. (Rdz 30, 16-17).

Tak samo autor opisuje poczęcie synów Dawida z Batszebą: zarówno tego, który umrze po narodzeniu (2 Sm 11, 4) jak i tego, któremu nadadzą imię Salomon:

Dawid okazywał współczucie dla swej żony Batszeby. Poszedł do niej i spał z nią [dosł.

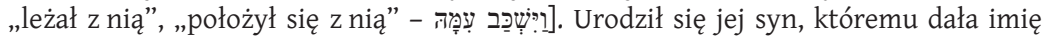
Salomon. A Pan umiłował go" (2 Sm 12, 24) .

\section{c) „wejść do" [בוא bô'].}

Tak np. autor opisuje współżycie Abrahama z Hagar, z której narodzi się Izmael:

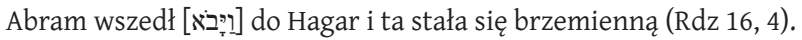

Tak zobrazowane jest współżycie Jakuba z Bilhą, z której narodzi się Dan:

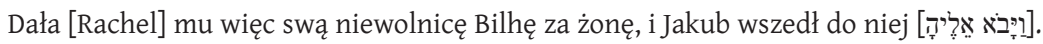
A gdy Bilha poczęła i urodziła Jakubowi syna, Rachela rzekła: „Bóg jako sędzia otoczył mnie opieką; wysłuchawszy mnie dał mi syna”. Dlatego nazwała go Dan ( $\operatorname{Rdz} 30,4-6)^{6}$.

4 W tłumaczeniu Biblii Tysiąclecia większość tych miejsc, w których czasownik „poznać” (ידע) oznacza akt seksualny, oddawana jest poprzez czasownik „zbliżyć się”: „Mężczyzna zbliżył się do swej żony Ewy” (Rdz 4,1); „Kain zbliżył się do swej żony” (Rdz 4, 17); „Adam raz jeszcze zbliżył się do swej żony" (Rdz 4, 25).

5 W ten sam sposób opisuje autor również współżycie córek Lota ze swoim ojcem, por. $\operatorname{Rdz} 19,32-36$.

6 W tłumaczeniu Biblii Tysiąclecia większość tych miejsc, w których czasownik „wejść” [בוא] oznacza akt seksualny, oddawana jest poprzez czasownik „zbliżyć się”: „Abram zbliżył się do 
d) „zbliżyć się” [حרāarab]

Tak opisane są narodziny syna Izajasza:

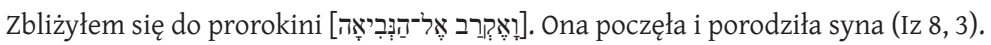

Podobnie próba współżycia Abimeleka z Sarą:

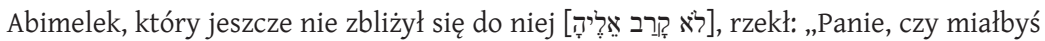
także ukarać śmiercią ludzi niewinnych?" (Rdz 20,4).

Również zapis prawny stosuje podobne określenie:

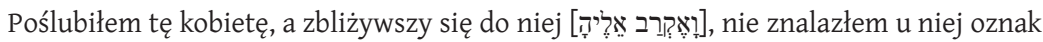
dziewictwa (Pwt 22, 14).

\section{e) „wziąć” [ח לקāqah]}

Chociaż w użyciu tego słowa najprawdopodobniej chodzi o moment zawarcia małżeństwa, to dwukrotnie występowanie czasownika w sekwencji „wziąć - począć - urodzić”, może sugerować iż również ten czasownik określa akt współżycia między kobietą i mężczyzną. Tak było z narodzeniem Mojżesza:

Pewien człowiek z pokolenia Lewiego przyszedł, aby wziąć [dosł. „przyszedł i wziął” - Iי.?] za żonę jedną z kobiet z tegoż pokolenia. Ta kobieta poczęła i urodziła syna (Wj 2, 1-2).

To samo określenie użyte jest w historii proroka Ozeasza:

Poszedł [Ozeasz] i wziął [חיוב? Gomer, córkę Diblaima, a ta poczęła i urodziła mu syna $(\mathrm{Oz} 1,3)$.

Analiza wyrażeń opisujących poczęcie człowieka prowadzi do kilku wniosków:

a) język hebrajski nie miał specjalnego czasownika na określenie aktu seksualnego. Wyrażenia opisujące ten akt są stosowane również do opisu innych czynności i tylko kontekst umożliwia takie a nie inne rozumie pojęćc. Jedynie syntagma „leżeć z, spać z” (hebr. שכב צ̌ šākab 'im] może

Hagar i ta stała się brzemienną” (Rdz 16, 4); „Dała mu więc swą niewolnicę Bilhę za żonę, i Jakub zbliżył się do niej" (Rdz 30, 4).

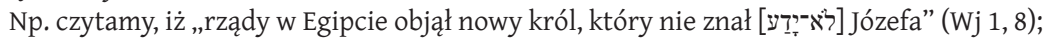

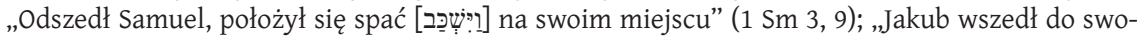


być rozumiana jako termin techniczny na określenie aktu seksualnego zarówno między ludźmi, jak i nawet między człowiekiem a zwierzęciem (por. Pwt 27, 21).

b) wyrażenia określające współżycie seksualne nie zależą od prawnej sytuacji osób ze sobą współżyjących. Stary Testament w ten sam sposób opisuje współżycie małżonka i żony, współżycie przedmałżeńskie (por. Pwt 22, 28) czy pozamałżeńskie (Pwt 22, 25), kazirodcze (por. Rdz 19, 3236; Pwt 27, 20), gwałt (por. Rdz 34, 2) a nawet współżycie ze zwierzęciem (por. Wj 22, 18).

c) akt seksualny nie prowadzi automatycznie do poczęcia człowieka. Mimo identycznych sformułowań używanych na oznaczenie współżycia nie zawsze prowadzi ono do powstania nowego życiå.

d) terminami technicznymi określającym powstanie nowego życia są przede wszystkim słowa związane z rdzeniem הרה hārāh „począć, być w ciąży" dlatego przyjrzyjmy się bliżej ich znaczeniu i zastosowaniu.

\section{Wokół semantyki הרה hārāh „począć, być w ciąży”}

Rdzeń hry „począć, być w ciąży” występuje również w języku ugaryckim, aramejskim i akadyjskim ${ }^{10}$. W języku hebrajskim do słów pochodzących od rdzenia הרה hārāh należą: a) czasownik „począć, być w ciąży” הרה hārāh (43×), b) przymiotnik "ciężarna, brzemienna” הָרֵ hāreh (16×),

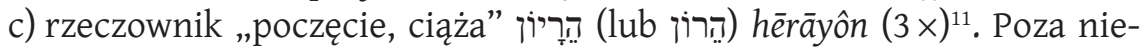

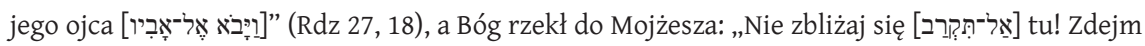
sandały z nóg, gdyż miejsce, na którym stoisz, jest ziemią świętą" (Wj 3, 5).

Por. np. historię Diny i Sychema, syna Chamora Chiwwity (Rdz 34) albo historię Tamar i Absaloma (2 Sm 13). W obydwu przypadkach autor nie mówi nic o ewentualnym poczęciu dziecka. Ponadto wszystkie przykłady niepłodności zakładają implicite wielokrotne akty seksualne niczym nie różniące się od tych, które dały początek nowemu życiu.

Por. M. Ottosson, , הרה hārāh", [w:] Theological Dictionary of the Old Testament [dalej: TDOT], red. G. J. Botterweck, H. Ringgren, Grand Rapids 1978, III, s. 458-461; V. Hamilton, „הרה", [w:] New International Dictionary of Old Testament Theology and Exegesis [dalej: NIDOTTE], red. W. A. VanGemeren, Grand Rapids 1997, I, s. 1057-1060.

10 Por. M. Ottosson, הרון hārāh", TDOT, III, s. 458.

11 הרוֹן (hērôn) może oznaczać również macierzyństwo, por. V. Hamilton, NIDOTTE, ,הרה", I, s. 1057. 
licznym użyciem rdzenia w sensie figuratywnym ${ }^{12}$ słowo ma za zadanie przekazać moment zajścia kobiety w ciążę i stan kobiety ciężarnej. Początek tego stanu jest zawsze wyrażany poprzez formę רֵַ Iַ wattahar ,i poczęła”.

Biblia nie wspomina o jakichś specjalnych rytuałach i środkach, które miałyby pomóc w szczęśliwym urodzeniu dziecka. Jedynym wyjątkiem jest żona Manoacha, która zanim urodzi Samsona, powinna się powstrzymać od picia wina i sycery (por. Sdz 13, 7). Nakaz ten jest jednak związany ze ślubem nazireatu obowiązującym jej dziecko, a nie z mniej lub bardziej znanym sposobem na udaną ciążę ${ }^{13}$.

Victor Hamilton zwraca uwagę na to, iż z reguły (poza nielicznymi wyjątkami, np. $1 \mathrm{Sm} 4,19$; Iz 8, 13), kiedy mowa jest o poczęciu, zawsze podane jest imię kobiety, która staje się matką dziecka. Matki nie są istotami niezidentyfikowanymi, których funkcją jest tylko przedłużenie rodzaju ludzkiego ${ }^{14}$ :

Mimo iż Biblia Hebrajska używa kilkadziesiąt razy słowa „począć, być w ciąży",nie ma ani jednego przypadku, w którym doszłoby do poronienia. Naturalną koleją rzeczy poczęcie prowadzi zawsze do narodzenia ${ }^{15}$. W dwu przypadkach jest tylko mowa o śmierci matki zaraz po urodzeniu $^{16}$. Częściej natomiast wspomina się o okrutnej praktyce rozpruwania ciężarnych kobiet. Elizeusz mówi z płaczem do Chazaela, przyszłego króla Aramu:

Wiem, co złego uczynisz synom Izraela: ich warownie zniszczysz ogniem, kwiat ich wojowników pozabijasz, ich drobne dzieci roztrzaskasz, a ich brzemienne kobiety będziesz rozpruwał $(2 \mathrm{Krl} 8,12)$.

12 Np. Ps 7, 14 mówi o poczęciu udręki i urodzeniu podstępu. Por także Lb 11, 12; Hi 15, 35; Iz 33,$11 ; 59,4$.

13 Według Talmudu [Nida 30] anioł uczy dziecko znajdujące się w łonie swej matki całej Tory. W tym samym paragrafie znajduje się stwierdzenie, że nigdy w życiu człowiek nie doświadcza większej radości niż w dniach kiedy znajduje się w łonie matki, por. S. Pecaric, Chumasz Pardes Lauder. Księga Pierwsza Bereszit, Kraków 2001, s. 158.

14 Por. V. Hamilton, NIDOTTE, ,הרה", I, s. 1058. Do wyjątków podanych przez autora należy dodać także bezimienną żoną Manoacha, matkę Samsona (por. Sdz 13, 2-24).

15 Do dyskusyjnego tekstu Wj 21, 22-25 wrócimy poniżej. Natomiast grecka Księga Tobiasza wspomina o niebezpieczeństwach, na jakie była narażona kobieta ciężarna: „Przypomnij sobie, dziecko, na jakie liczne niebezpieczeństwa była ona narażona z powodu ciebie, gdy cię w łonie swoim nosiła" (Tb 4, 4).

16 Rachel po urodzeniu Beniamina (por. Rdz 35, 16-20) i synowa kapłana Helego, żona Pinchasa po urodzeniu Ikaboda (por. 1 Sm 4, 19-22). 


\section{Prorok Amos zapowiada:}

Tak mówi Pan: Z powodu trzech występków synów Ammona i z powodu czterech nie odwrócę tego [wyroku], gdyż rozcinał brzemienne niewiasty Gileadu, by rozszerzyć swoje granice (Am 1, 13).

\section{Podobnie prorok Ozeasz:}

Samaria odpokutuje za bunt przeciw Bogu swojemu: poginą od miecza, dzieci ich będą zmiażdżone, a niewiasty ciężarne rozprute $(\mathrm{Oz} 14,1)$.

Okrucieństwo to dokonywane było także przez izraelskiego króla:

Menachem spustoszył Tappuach - zabijając wszystkich, którzy w nim byli - oraz okolice jego, począwszy od Tirsy, ponieważ mu nie otworzono bram. Spustoszył je, a wszystkie w nim brzemienne kobiety rozpruwał $(2 \mathrm{Krl} 15,16)$.

Powodem zabijania ciężarnych kobiet była prawdopodobnie chęć pozbawienia wrogów ewentualnych męskich potomków. Okrutna praktyka znana była wśród ludów semickich ${ }^{17}$.

Ciąża była stanem upragnionym (por. Rdz 30,17), a nieraz nawet wymodlonym (por. Rdz 25, 21; 1 Sm 1, 20), niepłodność zaś oznaczała hańbę (por. Rdz 30, 23). W czasach poligamii w niektórych przypadkach kobiety ciężarne lekceważyły swoje niepłodne konkurentki. Tak Hagar lekceważyła Sarę (por. Rdz 16, 4-5), a Peninna dokuczała Annie (por. 1 Sm 1, 2-7).

Na tle starotestamentowej afirmacji życia dwa teksty wydają się zaskakujące. Pierwsze słowa, które wypowiada Hiob do swoich przyjaciół, są zdecydowanym wyrazem wiary, iż lepiej byłoby się nie urodzić niż urodzić:

Niech przepadnie dzień mego urodzenia i noc, gdy powiedziano: „Poczęty mężczyzna”

[...] 0, niech ta noc bezpłodną się stanie i niechaj nie zazna wesela! (Hi 3, 3.7).

Słowa te, będące bardziej życzeniem niż przekleństwem, są wołaniem przeciwko wydarzeniom, które umożliwiły jego przyjście na świat: przeciw poczęciu i narodzeniu ${ }^{18}$. Ogrom cierpienia, które dotknęło Hioba, wypalił nie tylko bogactwo i uśmiercił dzieci, ale zabił w sercu jakąkolwiek

${ }_{17}$ Por. G. Widengren, Quelques remarques sur l'émasculation rituelle chez les peuples sémitiques, [w:] Studia Orientalia Ioanni Pedersen septuagenario dicata, Copenhagen 1953, s. 377-384.

18 Por. D. J. A. Clines, Job 1-20, Dallas 1998, s. 81 (Word Biblical Commentary). 
radość życia. Wartość poczętego życia jawi się w historii Hioba jako wartość względna.

W podobnym tonie wypowiada się prorok Jeremiasz:

Nie zabił mnie bowiem w łonie matki: wtedy moja matka stałaby się moim grobem, a łono jej wiecznie brzemiennym. Po co wyszedłem z łona matki? Czy żeby oglądać nędzę i utrapienie i dokonać dni moich wśród hańby? (Jr 20, 17-18).

Umiejscowienie w Biblii skargi Hioba i Jeremiasza z jednej strony pokazuje realizm życia, które może być tak trudne, iż nawet stan błogosławiony jawi się jako nieszczęście. Z drugiej jednak strony zarówno Hiob, jak i Jeremiasz, chociaż woleliby się nie urodzić, nie odbiorą sobie sami życia. Przejdą ekstremalnie trudne doświadczenia, które jednak będą miały swój koniec. Ostatnie słowa będą należeć do życia.

\section{Cztery fragmenty o życiu w łonie matki}

Pośród kilkudziesięciu starotestamentowych wzmianek o początkowym stadium życia człowieka można znaleźć kilka, które zdają się mówić trochę więcej o tym, co się może dziać i dzieje między poczęciem a narodzeniem. Przyjrzyjmy się czterem tekstom: Rdz 25, 21-24; Wj 21, 22-25; Hi 10, 8-13; Ps 139, 13-15.

\section{a) $\operatorname{Rdz} 25,21-24$}

Czterdziestoletni Izaak bierze sobie za żonę Rebekę, córkę Betuela. Niestety Rebeka jest niepłodna. Całą sytuację opisuje autor Genesis w następujący sposób:

Izaak modlił się do Pana za swą żonę, gdyż była ona niepłodna. Pan wysłuchał go, i Rebeka, żona Izaaka, stała się brzemienna. A gdy walczyły z sobą dzieci w jej łonie, pomyślała: "Jeśli tak bywa, to czemu mnie się to przytrafia?". Poszła więc zapytać o to Pana, a Pan jej powiedział: „Dwa narody są w twym łonie, dwa odrębne ludy wyjdą z twych wnętrzności; jeden będzie silniejszy od drugiego, starszy będzie sługą młodszego". Kiedy nadszedł czas porodu, okazało się, że w łonie jej były bliźnięta (Rdz 25, 21-24).

Zwróćmy uwagę na trzy elementy tego opisu. Po pierwsze bliźnięta, które walczą ze sobą w łonie Rebeki, autor nazywa הִָּּנִים habbānîm czyli ,synowie lub 
dzieci". Dzieci przed narodzeniem są określane w taki sam sposób jak po narodzeniu. Po drugie dzieci „walczyły ze sobą” w łonie Rebeki. Czasownik ץ rāṣaș znaczy zasadniczo „uciskać, gnębić, rozbić, zmiażdżyć” i we wszystkich 19 przypadkach użycia tego słowa podmiotem czynności jest zawsze człowiek. Ponadto czasownik ten bardzo często w Biblii używany jest na określenie uciskania ludzi ${ }^{19}$. Wybór takiego słowa rzuca światło na relacje, jakie będą zachodzić między potomkami Jakuba i Ezawa, czyli między Izraelitami i Edomitami. Po trzecie Bóg mówi Rebece na temat jej ciąży więcej niż ona będzie w stanie zobaczyć nie tylko po urodzeniu, ale nawet w przeciagu swojego życia. Nie tylko bowiem mówi o bliźniętach, ale widzi w jej łonie już dwa odrębne „na-

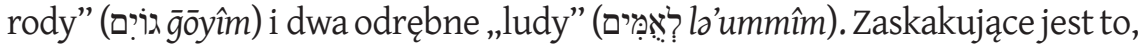
że autor nie mówi o tym, iż narody powstaną dopiero z dzieci, albo że synowie Rebeki będą protoplastami dwóch ludów, ale że to, co jest teraz w łonie Rebeki, to już są dwa narody i to, co wyjdzie w przyszłości z jej wnętrzności, już teraz nazywa dwoma ludami. Oczywiście można mówić o pewnym metaforycznym spojrzeniu na człowieka między poczęciem a narodzeniem. Ale może geniusz antropologii biblijnej polega na tym, że Bóg widzi w człowieku zawsze więcej niż sam człowiek widzi w sobie.

W tej samej perspektywie zrozumiałe jest słowo Pana skierowane do Jeremiasza:

Zanim ukształtowałem cię w łonie matki, znałem cię, nim przyszedłeś na świat, poświęciłem cię, prorokiem dla narodów ustanowiłem cię (Jr 1, 5) ${ }^{20}$.

Podobnie Sługa Pański u proroka Izajasza:

Wyspy, posłuchajcie Mnie! Ludy najdalsze, uważajcie! Powołał Mnie Pan już z łona mej matki, od jej wnętrzności wspomniał moje imię (Iz 49, 1).

Bóg widzi człowieka z perspektywy przyszłości, widzi go niejako w całości. Człowiek mając tylko swój spłaszczony ludzki horyzont może nie rozumieć Bożej perspektywy. Dlatego Jeremiasz się opiera (por. Jr 1, 6), podobnie jak opierał się Mojżesz (por. Wj 4, 10).

19 Np. Ammonici i Filistyni uciskali Izraelitów (por. Sdz 10, 7-8), a król Asa uciskał niektórych z ludu (por. 2 Krn 16, 10). Por. także Pwt 28, 33; 1 Sm 12, 4; Oz 5, 11; Am 4, 1.

${ }_{20}$ Por. także Syr 49, 7: „Skrzywdzili go bowiem, jego [Jeremiasza], który w łonie matki był poświęcony na proroka, aby wyrywał, tracił i niszczył, jak również budował i sadził". 


\section{b) Wj 21, 22-25}

To jeden z trudniejszych i bardziej kontrowersyjnych tekstów biblijnych. W tłumaczeniu Biblii Tysiąclecia (wyd. 5) brzmi następująco:

Jeśliby mężczyźni w czasie bójki uderzyli kobietę brzemienną, powodując poronienie, ale bez jakiejkolwiek innej szkody, to [winny] zostanie ukarany grzywną, jaką [na nich] nałoży mąż tej kobiety, i wypłaci ją za pośrednictwem sędziów polubownych. Jeżeli zaś ona poniesie jakąśs szkodę, wówczas on odda życie za życie, oko za oko, ząb za ząb, rękę za rękę, nogę za nogę, oparzenie za oparzenie, ranę za ranę, siniec za siniec.

Największe trudności znajdują się w wersach 22-23. Poniżej podaję przekład literalny z podkreślonymi miejscami, w których tekst hebrajski jest najbardziej niejasny:

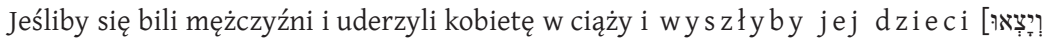

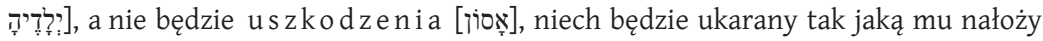

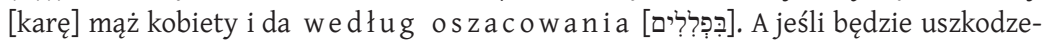
nie, dasz życie za życie...

Egzegeci poświęcili bezskutecznie tysiące stron w celu wyjaśnienia tego fragmentu ${ }^{21}$. Kilka kwestii pozostaje nadal niewyjaśnionych: a) dlaczego autor mówi o dzieciach w liczbie mnogiej? ${ }^{22}$; b) czy chodzi o poronienie czy przedwczesny, ale udany poród? ${ }^{23}$; c) co znaczy słowo אָ 'âsôn i czy dotyczy on kobiety i dziecka, czy tylko samej kobie-

21 Por. J. I. Durham, Exodus. Vol. 3, Dallas 1987, s. 323-324 (Word Biblical Commentary); W. H. C. Propp, Exodus 19-40. Vol. 2A, New Haven-London 2006, s. 121-122, 221-223 (Anchor Yale Bible); M. G. Kline, Lex Talionis and the Human Fetus, ,Journal of the Evangelical Theological Society” 20 (1977) s. 193-201; H. W. House, Miscarriage or Premature Birth: Additional Thoughts on Exodus 21: 22-25, „Westminster Theological Journal” 41 (1978) s. 108-123; J. M. Sprinkle, The Interpretation of Exodus 21: 22-25 (Lex Talionis) and Abortion, „Westminster Theological Journal” 55 (1993) s. 233-253; R. Fuller, Exodus 21: 22-23: The Miscarriage Interpretation and the Personhood of the Fetus, „Journal of the Evangelical Theological Society" 37 (1994) s. 169-184; M. Wojciechowski, Biblia o dzieciach nienarodzonych, za: http://www.opoka.org.pl/biblioteka/T/TB/biblia_aaborcja.html [26.01.2013].

22 Najczęściej tłumaczy się, że chodzi o bliźnięta albo o wyrażenie niesprecyzowanej materii, jaką jest człowiek przed narodzeniem, por. H. W. House, Miscarriage or Premature Birth: Additional Thoughts on Exodus 21: 22-25, art. cyt., s. 113-114; J. Lemański, Księga Wyjścia, Częstochowa 2009, s. 462 (Nowy Komentarz Biblijny).

23 Możliwe też, że wers 22 mówi o przedwczesnym porodzie, a wersy 23-25 o poronieniu, por. V. Hamilton, NIDOTTE, הרה", I, s. 1059. 
ty albo samego dziecka ${ }^{24}$; d) jak rozumieć wyrażenie e) czy słynną formułę lex talionis „życie za życie, oko za oko” należy rozumieć dosłownie, czy tylko o chodzi o odszkodowanie tak wielkie, na ile szacuje się wartość oka, ręki, nogi, według sposobu liczenia, ile tańszy jest człowiek, jeśli mu brak danej części ciała? ${ }^{26}$.

Pomimo powyższych trudności dwa wnioski wydają się pewne:

a) szkody, jakie może ponieść kobieta w ciąży nawet poprzez nieumyślnie zachowanie osób trzecich, muszą zostać zrekompensowane. Negatywny wpływ na ciążę widziany jest jako przestępstwo;

b) interpretacja tego fragmentu jako argumentu za tym, że płód ludzki nie jest osobą, jest nadinterpretacją. Nawet jeśliby odszkodowanie za poronienie lub jakąkolwiek inną szkodę nienarodzonego dziecka byłoby niższe od odszkodowania za człowieka dorosłego, nie jest to żadnym argumentem przeciw traktowaniu nienarodzonych dzieci jako nieosoby. Różnice odszkodowań świadczą o statusie społecznym, a nie o definicji człowieczeństwa ${ }^{27}$.

\section{c) $\mathrm{Hi} 10,8-13$}

W jednej ze swoich mów Hiob zwraca się do Boga:

Twe ręce ukształtowały mnie, uczyniły: opuszczonego dokoła chcesz zniszczyć?

Wspomnij, żeś ulepił mnie z gliny: i chcesz obrócić mnie w proch?

24 Słowo to występuje w Biblii tylko 5 razy. Może oznaczać uszkodzenie, zranienie, nieszczęście, złą przygodę, a może nawet śmierć. Poza tym fragmentem słowo to występuje tylko w historii Józefa na określenie ewentualnego nieszczęścia, które może spotkać Beniamina, por. Rdz 42, 4.38; 44, 29.

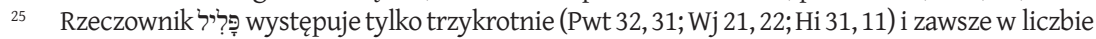
mnogiej. Najczęściej tłumaczony jest jako „sędziowie”, ,świadkowie” lub „oszacowanie”. Już Septuaginta

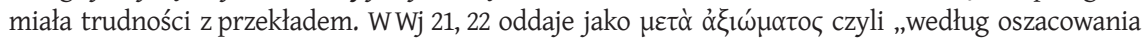
(wartości albo życzenia)". Zob. także B. S. Childs, Il libro dell'Esodo, Casale Monferrato 1995, s. 457.

26 Przeciw dosłownej interpretacji lex talionis wypowiadała się tradycja judaistyczna, natomiast za interpretacją dosłowną niektórzy współcześni egzegeci, por. H. W. House, Miscarriage Or Premature Birth: Additional Thoughts On Exodus 21: 22-25, art. cyt., s. 120-122.

27 Bardzo dobry zestaw argumentów walczących z opinią jakoby nienarodzone dziecko nie było osobą można znaleźć w R. Fuller, Exodus 21: 22-23: The Miscarriage Interpretation And The Personhood of The Fetus, art. cyt., s. 169-184. Autor konkluduje analizę starożytnych tekstów słowami: „The general view of the fetus in both the ancient Near East and the Bible contradicts the notion that the fetus is not a person. Through various literary forms, prayers and incantations, medical, royal, legal and omen texts, the ancient Near East supplies general information about the fetus and specific evidence for the personhood of the fetus", tamże, s. 176. 
Czy mnie nie zlałeś jak mleko, czyż zsiąść się nie dałeś jak serowi?

Odziałeś mnie skórą i ciałem i spiąłeś żyłami i kośćmi,

darzyłeś życiem, miłością, troskliwość Twa strzegła mi ducha -

a w sercu to ukrywałeś? Teraz już znam Twe zamiary.

Wersy 8-9 zdają się nawiązywać do idei ulepienia człowieka z gliny obecnej w Rdz 2, $7^{28}$. Zaskakujące jest to, że Hiob procesu tego nie odnosi do Adama, pierwszego człowieka, ale do siebie. Niejako w stworzeniu pierwszego człowieka widzi stworzenie siebie. Być może w ten sposób podkreśla swoją przynależność do rodzaju ludzkiego, której ceną jest również ostateczne obrócenie się w proch (por Rdz 3, 19).

Następnie w wersie 10 przechodzi do obrazu mleka, które wlane (w ciało człowieka), ścina się i tworzy ser (albo zsiadłe mleko) ${ }^{29}$. Niewątpliwie chodzi tu o wyobrażenie autora na temat powstawania człowieka. Nasienie mężczyzny przekazane kobiecie w czasie współżycia porównane jest do czynności wlewania mleka. Natomiast proces tworzenia się ciała do tworzenia się sera. Do tego trzeba jeszcze dodać skórę i ciało, którymi człowiek jest przyodziany, i ścięgna oraz kości, które Bóg sam utkał (w. 11).

W wersach 12-13 Hiob kontynuuje opis powstawania siebie, dodając, że Bóg uczynił z nim życie i łaskę, czyli obdarzył go tymi darami, a ponadto otoczył go swoją troskliwą opieką.

W opisie powstawania człowieka z jednej strony Hiob prezentuje poglądy zgodne z panującymi wówczas teoriami na temat powstawania życia ${ }^{30}$. Z drugiej jednak strony przypisuje każdy kolejny etap tworzenia się człowieka Bogu. W ten sposób życie ludzkie jest całkowicie zależne od działania Stwórcy ${ }^{31}$. Tak jak nie da się pomyśleć powstania pierwszego człowieka

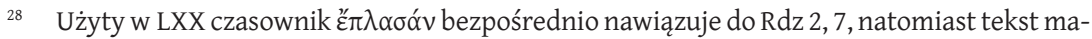
sorecki w Hi 10,8 używa czasownika עצב 'āṣab „formować”, kszałtować”.

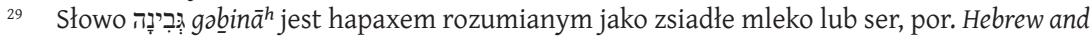
Aramaic Lexicon of the Old Testament $i$ Enhanced Brown-Driver-Briggs Hebrew and English Lexicon ad vocem. Septuaginta tłumaczy tupó jako „ser”.

30 Podobny obraz znajdujemy w Ps 139, 13-16; 2 Mch 7, 22-23; Koh 11, 5; Mdr 7, 1-2. Także w Koranie (Sura 22.5; 36.76; 40.69; 80.19; 96.2) u Pliniusza (Historia naturalis 7.13) czy w Talmudzie (Pirqe Abot 3.1), por. także D. J. A. Clines, Job 1-20, dz. cyt., s. 248; G. Ravasi, Hiob, przeł. K. Stopa, Kraków 2005, t. 2, s. 144.

31 Egzegeci podkreślają, że również idea tworzenia człowieka z gliny obecna w wersie 8 ma podkreślić całkowitą zależność człowieka od Boga, por. Iz 45, 9; Jr 18, 5-12 oraz M. H. Pope, Job New Haven-London 1974, s. 80 (Anchor Yale Bible). 
bez ingerencji Stwórcy, tak powstanie każdego kolejnego życia jest dziełem boskiej czynności. Człowiek jest bytem stającym się w rękach Boga ${ }^{32}$.

\section{d) Ps 139, 13-15}

Psalm 139 prawie w całości poświęcony jest wiedzy Boga o człowieku. Po początkowych wersetach, w których psalmista odsłania wieloaspektowe poznanie człowieka przez Boga, następuje kilka wersetów, które odnoszą się do życia między poczęciem a narodzeniem:

Ty bowiem utworzyłeś moje nerki, Ty utkałeś mnie w łonie mej matki.

Dziękuję Ci, że mnie stworzyłeś tak cudownie, godne podziwu są Twoje dzieła.

I dobrze znasz moją duszę,

nie tajna Ci moja istota, kiedy w ukryciu powstawałem, utkany w głębi ziemi.

Wzmianka o utworzeniu nerek może albo odnosić się do fizycznych wnętrzności człowieka, które Bóg dosłownie utkał ${ }^{33}$, albo być odczytana w sensie figuratywnym: Bóg zna najskrytsze pragnienia człowieka, gdyż nerki są siedliskiem uczuć i pożądańn ${ }^{34}$.

Utkanie w łonie matki wskazuje z jednej strony na delikatność i misteryjność procesu powstawania człowieka, jak również na ponadludzką możliwość działania Boga, który potrafi działać tam, gdzie człowiek nie ma nawet dostępu.

Początek wersu 14 można przetłumaczyć: „Będę Ci dziękował, ponieważ zostałem wyróżniony w sposób robiący wrażenie, cudowne są dzieła twoje". Idea tekstu hebrajskiego jest dosyć klarowna. Człowiek jest dziełem Boga, cudownym i wyróżnionym ponad inne dzieła. Czasownik פלālā' znaczy nie tylko „być cudownym”, ale również „być odseparowanym”, „być da-

32 Według N.C. Habela w opisie Hioba chodzi nie tyle o biologiczny opis powstawania człowieka, co o podkreślenie tajemnicy i intymności, z jaką Bóg jest zaangażowany w prenatalny wzrost człowieka, por. N. C. Habel, The Book of Job, Philadephia 1985, s. 199.

33 Tak J. Goldingay, Psalms. Vol. 3. Psalms $90-150$, Grand Rapids 2008 , s. 633. F. L. Hossfeld zwraca jednak uwagę, iż nie chodzi tu tylko o nerki, ale całe wnętrze człowieka, por. F. L. Hossfeld, E. Zenger, Psalmen 101-150, Freiburg-Basel-Wien 2008, s. 723 (Herders Theologischer Kommentar zum Alten Testament).

34 Por. S. Łach, Księga Psalmów, Pismo Święte Starego Testamentu, Poznań 1990, s. 561. 
leko ponad; dużo więcej niż”35. Chodziłoby o wyróżnienie człowieka ponad inne stworzenia. Podobną myśl mamy w Psalmie 8.

"Moja istota" w wersie 15, która nie jest tajna przed Bogiem, a skryta przed człowiekiem, to dosłownie „moje kości, mój szkielet”, struktura będąca niejako materią fundamentalną, nośną całego człowieka ${ }^{36}$.

Głębia ziemi, w której został utkany psalmista, odnosi się najprawdopodobniej do łona matki ${ }^{37}$. Skoro ziemia jest naszą matką i z niej powstał człowiek, to każdy rodzący się człowiek niejako powstaje z ziemi, łono matki jest ziemią każdego człowieka ${ }^{38}$.

Psalmista mówi, iż został utkany w głębi ziemi. Czasownik רִ rāqam w koniugacji Pual przybiera sens „być utkanym, uformowanym”, ale odnosi się do procesu tkania materiałów kolorowych, tkanin wielobarwnie wyszywanych ${ }^{39}$. Fakt, iż oprócz Ps 139 czasownik został użyty tylko w kontekście wyrabiania tkanin na potrzeby przybytku ${ }^{40}$, może sugerować, że człowiek jest nie tylko utkany przez Świętego, ale jego miejsce jest blisko tego, który go uczynił.

\section{e) Pozostałe fragmenty o życiu przed narodzeniem}

Oprócz wspomnianych wyżej fragmentów Stary Testament wspomina jeszcze kilkakrotnie o życiu w łonie matki.

W rozdziale 12 Księgi Liczb autor opisuje narzekanie Miriam i Aarona na Mojżesza. Bóg ukarał za to trądem siostrę Mojżesza. Wtedy Aaron powiedział do brata:

Proszę, panie mój, nie karz nas za grzech, któregośmy się nierozważnie dopuścili i jesteśmy winni. Nie dopuść, by ona stała się jak martwy [płód], który na pół zgniły wychodzi z łona swej matki (Lb 12, 11-12).

Życie trędowatego porównane jest do martwego noworodka, którego ciało jest w połowie skonsumowane, zjedzone, kiedy się rodzi. Nie do końca zrozumiała jest idea bycia skonsumowanym, zepsutym w połowie,

\footnotetext{
35 Tak Sforno i Rabbi Yehudah HaLevi, por. A. C. Feuer, Tehilim, New York 2004, s. 1640.

36 Por. L. A. Schökel, C. Carniti, I Salmi, Roma 1993, t. 2, s. 790.

37 Por. S. Łach, Księga Psalmów, dz. cyt., s. 561; L. A. Schökel, C. Carniti, I Salmi, dz. cyt., s. 790.

38 Por. J. Goldingay, Psalms. Vol. 3. Psalms 90-150, Grand Rapids 2008, s. 635.

39 Por. F. L. Hossfeld, E. Zenger, Psalmen 101-150, dz. cyt., s. 724.

40 Por. Wj 26, 36; 27, 16; 28, 39; 35, 35; 36, 37; 38, 18.23; 39, 29.
} 
stąd w komentarzach egzegeci zatrzymują się tylko na porównaniu trądu $\mathrm{z}$ urodzeniem martwego dziecka ${ }^{41}$. Oczywistym w tym kontekście jest to, że przypadki urodzenia martwego dziecka były faktem znanym.

W Rt 1,11 Noemi mówi do swoich synowych:

Wróćcie, moje córki, czemu idziecie ze mną? Czyż mam jeszcze w swoim łonie synów, którzy mogliby zostać waszymi mężami?

To, co Noemi mogłaby mieć w łonie (dosł. we wnętrznościach), nazywane jest בָזִ bֵânîm „synami, dziećmi”. Nie ma różnicy istotowej między nienarodzonym a narodzonym dzieckiem.

W Hi 3, 16 Hiob kontynuując lament nad swoim życiem, mówi:

Nie żyłbym jak płód poroniony, jak dzieci, które nie widziały światła.

Po pierwsze tekst odnosi się do przypadków urodzenia martwych dzie-

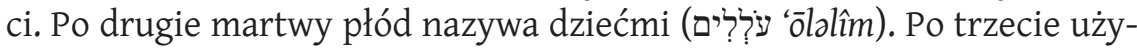

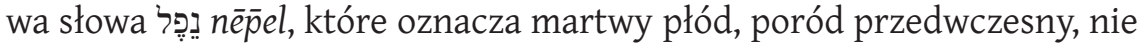
w porę, a może nawet aborcję ${ }^{42}$ Poza Hi 3, 16 słowo to występuje tylko w Ps 58, 9 („Niech przeminą jak ślimak, co na drodze się rozpływa, jak płód poroniony, co nie widział słońca”) oraz w Koh 6, 3 („Gdyby ktoś zrodził nawet stu synów i żył wiele lat, i dni jego lat się pomnożyły, lecz dusza jego nie nasyciła się dobrem i nawet pogrzebu by nie miał - powiadam: Szczęśliwszy od niego nieżywy płód")

W Ps 51, 7 autor mówi:

Oto zrodzony jestem w przewinieniu i w grzechu poczęła mnie matka.

Oprócz idei naturalnej skłonności do zła wspólnej wszystkim ludziom ${ }^{43}$ moment poczęcia zostaje związany z czasownikiem יחם yāham „być gorą-

41 Por. P. J. Budd, Numbers, Dallas 1998, s. 137 (Word Biblical Commentary); B. A. Levine, Numbers 1-20, New Haven-London 2008, s. 333 (Anchor Yale Bible).

${ }_{42}$ Por. M. H. Pope, Job, dz. cyt., s. 31. Według Clinesa słowo to nie oznacza poronienia czy aborcji, ale martwy płód, por. D. J. A. Clines, Job 1-20, dz. cyt., s. 95.

${ }_{43}$ Por. Rdz 8, 21; $1 \mathrm{Krl} 8$, 46; Hi 4, 17; 14, 4; 15, 14; 25, 4; Prz 20, 9. Komentując ten fragment, Augustyn stwierdza, że każda istota ludzka jest grzeszna od poczęcia, a Hieronim, że dziecko nawet w pierwszym dniu po poczęciu jest grzeszne, por. Q. F. Wesselschmidt, Psalms 51-150, Downers Grove 2007, s. 5 (Ancient Christian Commentary on Scripture OT). 
cym”. Zapewne Raszi ma rację, kiedy widzi w tym związek z intensywnością pożądania, jakie towarzyszy współżyciu seksualnemu ${ }^{44}$.

Kohelet podkreśla tajemniczość powstawania człowieka:

Jak nie wiesz, którą drogą duch wstępuje w kości, co są w łonie brzemiennej, tak też nie możesz poznać działania Boga, który sprawuje wszystko (Koh 11, 5).

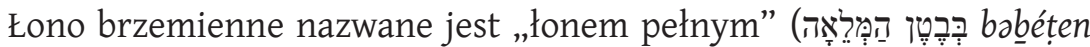
hammolè' $\bar{a}^{h}$ ), a wzmianka o duchu (wietrze) ma tylko podkreślić nieprzewidywalność i nieznajomość dróg Bożych ${ }^{45}$. Jednym z misteriów Boga jest początek człowieka.

O misterium początków człowieka mówi też grecka część Starego Testamentu. Matka siedmiu gotowych na męczeństwo synów dodawała im odwagi między innymi słowami:

Nie wiem, w jaki sposób znaleźliście się w moim łonie, nie ja wam dałam tchnienie i życie, a członki każdego z was nie ja ułożyłam. Stwórca świata bowiem, który ukształtował człowieka i wynalazł początek wszechrzeczy, w swojej litości ponownie odda wam tchnienie i życie, dlatego że wy gardzicie sobą teraz dla Jego praw (2 Mch 7, 22-23).

Wers 22 podkreśla nie tylko brak dokładnej wiedzy na temat początku człowieka, ale przekonanie, iż matka dziecka nie jest ani dawcą życia, ani tą, która to życie w jej łonie kształtuje (dosł. „układa według pewnego planu"). Skoro w wersie 23 pojawia się wspomniana już idea Boga formującego człowieka (por. Rdz 2, 7), to tym, który jest odpowiedzialny za powstanie i rozwój życia prenatalnego, może być tylko Bóg ${ }^{46}$.

Ciekawą ideę zawiera też Księga Mądrości 7, 1-2:

I ja jestem człowiekiem śmiertelnym, podobnym do wszystkich, potomkiem prarodzica powstałego z ziemi. W łonie matki zostałem ukształtowany jako ciało, w ciągu dziesięciu miesięcy, we krwi okrzepły, z nasienia męskiego, i rozkoszy ze snem złączonej.

Mówiąc o potomku powstałym z ziemi, autor wyraźnie odnosi się do Rdz 2, 7. To samo odniesienie do Boga twórcy, rzeźbiarza widoczne jest

${ }^{44}$ Por. A. C. Feuer, Tehilim, dz. cyt., I, s. 655.

45 Por. C. L. Seow, Ecclesiastes, New Haven-London 1997, s. 345-346 (Anchor Yale Bible).

46 Idea ta zostanie wielokrotnie podkreślona również w innych miejscach: „Jak mnie, tak jego we wnętrzu uczynił, On sam nas w łonie utworzył” (Hi 31, 15); „Tak mówi Pan, twój sprawca, twój twórca od narodzenia, twój wspomożyciel” (Iz 44,2); „Tak mówi Pan, twój Odkupiciel, Twórca twój jeszcze w łonie matki" (Iz 44, 24). 
w drugiej części wersetu, pisze bowiem „W łonie matki zostałem wyrzeźbiony ( sięciomiesięcznym okresie ciąży ${ }^{47}$, a także o trzech elementach konstatujących człowieka: krwi, nasieniu ojca i przyjemności połączonej ze snem. Przyjemność zapewne jest eufemistycznym zwrotem na określenie współżycia seksualnego ${ }^{48}$. Natomiast wzmianka o krwi odnosi się najprawdopodobniej do znanej wówczas teorii, iż do poczęcia człowieka potrzebna jest menstruacyjna krew kobiety ${ }^{49}$.

\section{Synteza}

Próba uporządkowania starotestamentowej myśli na temat życia przed narodzeniem człowieka nie jest równoznaczna z wyczerpującą analizą tematu. Chodzi raczej o zauważenie i podkreślenie pewnych powtarzających się idei. I tak:

a) Człowiek nie może się począć i rozwijać bez czynnego aktu Boga. Żadne poczęcie, nawet nielegalne i grzeszne, nie jest interpretowane jako pomyłka, niewiedza lub brak działania Boga. Co więcej, zdecydowana większość tekstu mówi o Boskim udziale w powstawaniu człowieka. Bóg jest o wiele ważniejszym czynnikiem w powstawaniu człowieka niż jego rodzice.

b) Człowiek zostaje poczęty dzięki współżyciu mężczyzny i kobiety. Żaden tekst (poza stworzeniem pierwszych ludzi) nie mówi o jakiejkolwiek innej formie początku życia.

c) Nie można wyodrębnić istotowej różnicy między dzieckiem nienarodzonym a narodzonym. Nazywane są tak samo dziećmi i synami, często widziane jako w pełni uformowani ludzie i narody; stosuje się do nich określenia wzięte z relacji między ludźmi dorosłymi.

d) Dziecko nienarodzone jest darem i wartością, którego naturalnym, upragnionym i zasadniczym celem jest przyjście na świat. O zabijaniu nienarodzonych dzieci mówi się tylko w kontekście wojny i podejmują się

47 Liczono zapewne miesiące księżycowe, stąd rozwiązanie następowało w miesiącu dziesiątym, por. J. Vílchez Líndez, Sapienza, Roma 1990, s. 279-280.

48 Por. tamże, s. 280.

49 Takie zdanie podzielali też Arystoteles, Hippokrates, a nawet indyjska Suśruta-Saṃhita, por. D. Winston, The Wisdom of Solomon, New Haven-London 1979, s. 164 (Anchor Yale Bible). 
tego tylko ci, którzy są wrogami. Stary Testament, chociaż obfituje w niezliczone opisy mniej lub bardziej uzasadnionych zabójstw, nie wspomina ani razu o świadomej aborcji dokonanej przez rodziców dziecka.

e) Wiedza biologiczna na temat rozwoju człowieka w stadium prenatalnym zasadniczo odpowiada ówczesnym poglądom. To, co wyróżnia myśl biblijną, to udział Boga w powstawaniu człowieka.

\section{Summary}

Life of an Unborn in Old Testament

The article aims to analyze the old Testament's idea of life before birth. Firstly, I examine some expressions describing sexual intercourse. Secondly, I study the meaning of the word הרה härāh "to conceive". Thirdly, I analyze some crucial texts (ad es. Rdz 25, 2124; Wj 21, 22-25; Hi 10; Ps 139). At the end, I offer a brief synthesis of the Old Testament's idea about life between conception and birth.

Keywords: Old Testament, conception, unborn, foetus

Słowa kluczowe: Stary Testament, poczęcie, nienarodzony, powstanie człowieka, płód 